\title{
How Can New Online P2P Lending Platform Catch up from Behind-Take Ebaodai as an Example
}

\author{
Jianfei Leng ${ }^{1,2 *}$, Qiaoyun Ye ${ }^{1}$ \\ ${ }^{1}$ Business College of Hohai University, Nanjing, China \\ ${ }^{2}$ Management College of Fudan University, Shanghai, China \\ Email: "1140980017@qq.com
}

Received 8 October 2015; accepted 29 November 2015; published 2 December 2015

Copyright (C) 2015 by authors and Scientific Research Publishing Inc.

This work is licensed under the Creative Commons Attribution International License (CC BY). http://creativecommons.org/licenses/by/4.0/

(c) (i) Open Access

\begin{abstract}
Internet finance has become extremely popular since 2013, especially online P2P lending, which appears like mushrooms. And at the same time, the number of problematic platform is rising. Many platforms appeared to be difficult to withdraw deposit; some had even closed. For the lack of supervision and credit system in our country, this article takes the up-rising star Ebaodai as the research object to analyze its business model and characteristic of platform running. Then the article explored and analyzed how new P2P lending platform to stand out among numerous newly increased ones from a platform standpoint.
\end{abstract}

\section{Keywords}

P2P Lending Platform, Business Model, Use for Reference

\section{The Development of the Domestic P2P Lending Platform}

P2P is the abbreviation of "Peer to Peer Lending", which is usually translated as "Everyone Credit" in our country. It is a kind of "individual to individual, point to point" lending model. The world's first P2P lending plat form Zopa formally launched in March 2005 in London. Then Prosper established in February 2006 in the United States. Since the first domestic P2P platform—Shanghai Ppdai officially established in August 2007, P2P credit is showing a blowout type development in our country. According to the statistics of data.01caijing.com, the number of operating platform is only about 50 before 2011, and it had risen up to 200 in 2012, 800 in 2013 and 1575 in 2014, which is more than seven times higher than that in 2012. According to the incomplete statis-

${ }^{*}$ Corresponding author. 
tics of eye data research center, the number of P2P net loan platform has increased to 2531 by April 30, 2015. As shown in Chart 1, the number of domestic P2P platform almost presented a trend of exponential growth.

In addition, the data of http://www.wangdaizhijia.com/ showed that the total volume of P2P platform is 252.8 billion in 2014, and Hong Ling Capital ranked first with its turnover reached 17.82529 billion. Although located in the first place, the proportion of venture capital in the industry is only $7 \%$, and the rest of the platform is even smaller.

With the rapid development of P2P net loan, the problematic platform began to emerge in an endless stream. Chart 2 shows the number of normal platforms and problematic platforms that are added to each month from January 2014 to March 2015. This shows that the problematic platform appeared every month among the newlyadded platform. The problematic platform has even risen up to 36 in November 2014. 41.18\% of the platforms have the difficulty withdrawing deposit. As shown in Chart 3.

The above analysis showed that P2P platform is currently in the state of vigorous development, it neither formed a single party nor a monopoly. The market let a hundred schools of thought contend, and living space for the emerging enterprises is huge. However, many of these new platforms also have problems, except the lack of

The number of operating platforms

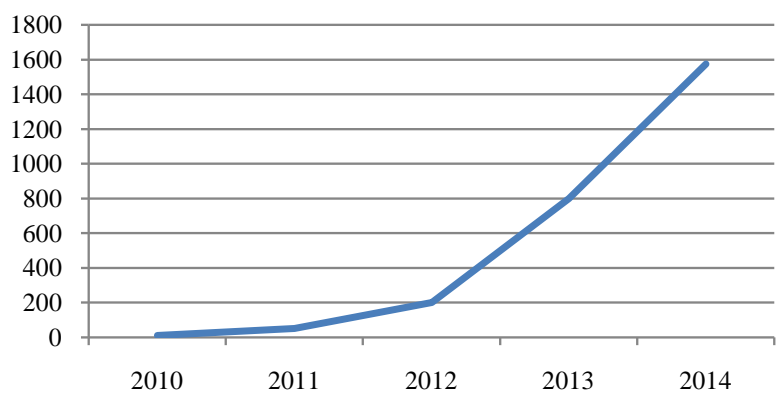

Chart 1. The growth trend of the number of operating platforms.

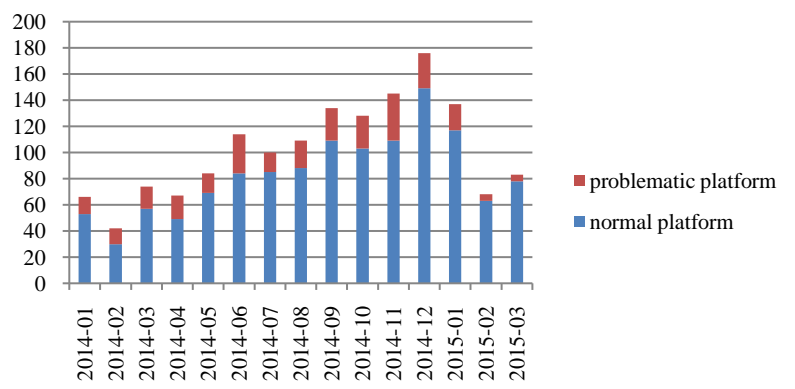

Chart 2. Basic facts about newly increased platforms from Jan. 2014 to Mar. 2015.

Performance distribution of problematic platforms in 2014

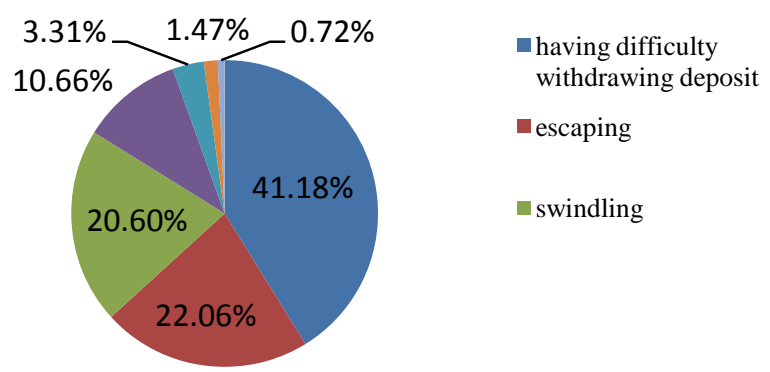

Chart 3. Performance distribution of problematic platforms in 2014. 
supervision and credit system and the wrong understanding of the nature of $\mathrm{P} 2 \mathrm{P}$ lending, the most important reason is their poor management and weak awareness of risk. Li Xian ling [1] made an empirical research on the 111 problematic P2P and found that: management experience has a significant positive impact on the survival time of the problematic platforms. This article explored how to manage itself to obtain healthy and rapid development from the perspective of the P2P platform.

\section{Ebaodai and the Reason of Its Success}

\subsection{About Ebaodai}

Ebaodai is a financial information service plat form subordinate to Guangdong Ebaodai Asset Management Co, Ltd, which formally launched in June 25, 2014. It first created a new internet financial investment model: "investors-Ebaodai-cooperative institution-borrowers" both online and offline with the combination of platforms and institutions. It is one of the P2P platforms that first truly realized third party funds custodian as well as introduce third party guarantees, third party asset valuation and third party law office as cooperative institution. It is also the first landed Guangzhou equity trading center, the first settled in Guangzhou Internet Financial Industry Park. Its total amount of transactions exceeded one hundred million in only half a year in 2014. On April Fool' sday in 2015, the total amount of the transaction exceeded 2 hundred million with no overdue or bad loan.

\subsection{Analysis of the Success of Ebaodai}

1). The key is business model innovation

Ebaodai cooperated with the third parties both online and offline instead of using the traditional mode. Cooperated institutions carry out the examination and verification of qualification of borrower offline, and Ebaodai internet financial information service platform pick out investors online. It chooses the perfect qualified and reliable loan companies, asset evaluation companies, guarantee agencies and law firms as partners. It initially verifies borrowers through the mechanism of risk control and reexamines by asset evaluation companies and guarantee agencies, the law office conducts the second audit over loan qualification and the validity of the pledge. Only the high quality project would release on the Ebaodai platform. This model has its advantages over other P2P platform, the risk is blocked outside the cooperation companies through assessment and audit layer by layer. Although it will reduce some business, it protects the security of the platform investors [2]-[5].

2). 10 major security systems

a). Strict access system. Ebaodai sets up a strict access system to examine the financial strength, credit status, operating conditions, risk control ability and debt-paying ability of cooperated companies, only the approved and qualified companies have the opportunity cooperating with the platform to provide users with services.

b). Multi security examination over project. It includes on-the-spot investigation, examination of information, assetassessment, debt-paying ability assessment, mortgage management and the second examination.

c). Real third party's funds custody. Ebaodai first adopts third party's funds custody, which realizes the separation of the funds between the platform, debtor and creditor and cooperative companies. It provides investors with secure funds management.

d). Joint liability guarantee of the institution. Ebaodai directly requested for compensation and debt repurchase instead of traditional form of security. All the loan programs are recommended by cooperated companies which also offered joint liability guarantee. It also requested to provide $100 \%$ guarantee of principal and interest for each loan projects. Once the loan project appeared overdue risks, Ebaodai would ask the company to pay $100 \%$ advanced principal and interest to protect the safety of investors' principal and interest.

e). Loan loss provision. It consists of two parts: initial insurance and project insurance. Initial insurance (10 million) was invested by Ebaodai at the very first time to deal with possible overdue risk; project insurance came from each loan projectof a certain proportion. Thus the continual accumulated loan loss provision can guarantee the safety of principal and interest of investors.

f). Third party's asset value assessment. Ebaodai took the lead in introducing the third party asset appraisal institution. It offered professional and objective value assessment by field visiting of underlying projects' guarantee and pledge, which can determine a reasonable amount of loan money to ensure the legal rights and interests of debit and credit sides.

g). Consultant guidance of professional service. Ebaodai provides customers with financial guidance, project 
funds flow tracking, repayment remind and investment advice by their professional consultant team. VIP memberseven can enjoy a one-to-one investment guidance.

h). A whole-process escort offered by leading financial experts. Ebaodai established the best advisory team to provide consultant guidance for its development by inviting the leading financial experts nationwide. The experts team brought continual wisdom for Ebaodai from policy judgments, market analysis, user requirements, product design and service upgrades in a all-round way. For users, it provides professional, safe, and leading business security.

i). Lawyers to provide legal protection. Ebaodai cooperates with authoritative law office to offer the platform with full legal advice and consultants. It ensures that the platform and the parties operate in line with national policies and regulations and protect the interests of all parties.

j). Technical security of the platform. Ebaodai is relying on Ali's strong cloud hardware and network. With the use of double server interactive data management on cloud and offline and the adoption of security design of the system architecture, it identified as SSL global trusted site.

3). Strict audit process of risk control

The financial projects released on Ebaodai platform are high quality projects recommended by the cooperative organizations. After the loan application launched by the borrowers, cooperative agencies, Ebaodai risk control team and Ebaodai audit committee would carry out the examination. Afterwards, adopted projects can invite bids on Ebaodai platform. All these can guarantee the investment security of investors.

4). Cooperate with banks

Ebaodai reached strategic cooperation with Guangdong conghualiuyin village bank partnership company (which subordinate to Huizhou Bank) on October 2014. They carry out internet financial information service of bank financial products together. Ebaodai became the first platform to cooperate deeply with bank.

The cooperation, on the one hand, is expanding the bank's business channels, helping to develop new products and services and improving the efficiency of bank loan projects; on the other hand, with strong financial strength of the bank, Ebaodai projects obtain more insurance, which can improve the confidence and investment enthusiasm of investors.

\section{Reference for New P2P Platform}

From the above analysis, Ebaodai's healthy fast development can't live without its own management. We can also get some good lessons from its development process.

\subsection{Find the Right Person}

Ebaodai can hardly do without its strong professional team. Its head office Guangdong Ebaodai assets management Co., Ltd. is a professional investment management organization made of senior experts from asset management, risk management, financial investment and the high tech field all over the country. While the shareholders and company backgrounds vary greatly in current Chinese P2P platform. For there are no clear laws and policies to follow as well as mature management experiences to refer, the position of current Chinese P2P industry is unclear. So operators must find the balance point between the legal red line, business development and risk control, which request the operators have a solid financial service background. Therefore, the employees need to have the relevant financial background from the perspective of long-term health development of the industry.

\subsection{Business Model Innovation}

The business model of P2P mainly has two kinds: on-line and the combination of online and online. Most P2P platforms in our country use the combination of online and offline mode due to the lack of credit rating system. The major problem this model has is that only a few platforms have professional funds management companies or specialized funds management Cooperation Bank, most of their funds are managed by the third party payment platform. Ti is essentially the platform itself responsible for the supervision of funds. So the problematic platforms (Chart 3 shows, including having difficulty withdraw deposit, escaping, swindling) make up $85.84 \%$ in recent years. From the above analysis about Ebaodai's success, business model innovation plays a very important role. 


\subsection{Technical Security}

Technology come down to the normal and stable operation of the platform, prevention of hacking, leakage of users information and other key issues, so the platform must have a strong technical construction team to use the database, data structure, data analysis software and a variety of programming languages to construct a safe and reliable platform.

\subsection{The Platform Itself Should Strengthen the Risk Control}

A good risk control system can disperse and control risk. Ebaodai's risk control audit process perfectly ensures the safety of investors' funds. P2P platforms should establish their own risk control system based on the platform's profit modelto protect the safety of investors' funds. Only in this way can they attract investors to lend, achieving a virtuous circle of profit.

\subsection{Disclose Plat Form Data, Ensure a Transparent Net Loan Environment}

The transparency of information is very important for stakeholders to companies and governments. Domestic P2P Platforms always ignore the issue of information disclosure. Investors and borrowers are skeptical about many P2P platforms in our country. This goes against the supervision of relevant state organs. In this regard, P2P platform should disclose the relevant information and actively communicate with investors and borrowers. Good information disclosure can improve the transparency of its operations, which is not only the requirements of investors and borrowers, but also necessary part of future supervision.

Ebaodao's website has detailed information about its operation. Investors can see the amount of investment per month, the amount of repayment, data of assignment of debt, evaluation data of risk tolerance and other relent data, which is greatly improving the trust of investors.

\section{Conclusion}

China's P2P net loan industry is developing rapidly; new platforms emerge in large numbers. For lack of legal supervision since it has been born in our country, its development is not standard; hidden risk becomes exposed. Many platforms close down for all kinds of reasons, which bring a serious blow to the credibility of the industry. The healthy development of the new P2P platform has important practical significance to the stability of the financial order in our country.

\section{References}

[1] Zhang, Q. (2013) The Research on Operating Mode and Risk Control of P2P Net Loan Platform. Decision and Information, No. 8.

[2] Li, X.L. (2015) Empirical Analysis on the Reasons of Bankrupt P2P Net Loan Platform. Research of Financial Development, No. 3.

[3] Li, B. and Wang, J. (2015) Problems and Suggestions of the Development of the Domestic P2P Net Loan Platform. Era of Finance, No. 1.

[4] Zhang, X.F., Wu, T.H., Zhang, C.Y., et al. (2015) Exploration of Working Way of P2P Platform under the Collapse Tide. Manager, No. 5.

[5] Kong, L.J. (2014) Final Puzzle and Bottom Line of Solution ODP2P Net Loan Platform. Financial Supervision, No. 7. 